\title{
PROPERTI DETERMINAN NILAI PERUSAHAAN dan REAL ESTATE PADA PERIODE GENCARNYA PEMBANGUNAN INFRASTRUKTUR
}

\author{
Riza Fajarnia \\ Yuni Rimawati* \\ Emi Rahmawati \\ Universitas Trunojoyo Madura, Jalan Raya Telang, Kecamatan Bangkalan, Madura \\ yuni.rimawati@trunojoyo.ac.id
}

\author{
A R T I C L E I N F O \\ Article history: \\ Received March 2, 2019 \\ Revised April 10, 2019 \\ Accepted April 18, 2019
}

Key words:

Capital Structure, Investment Opportunity Set, Liquidity, Profitability, Firm Value

\begin{abstract}
A B S T R A C T
This research aim to obtain empirical evidence about the determinant of firm value property and real estate in the period of incessant infrastructure development. Independent variables used in this research were capital structure as measured by debt to equity ratio (DER), investment opportunity set measured by market to book ratio (MBA), liquidity measured by current ratio (CR), and profitability measured by return on equity (ROE). Dependent variable was firm value measured by the price to book value (PBV). Control variable was size of firm. Population used in this research are property and real estate companies listed Indonesian Stock Exchange in period 2014-2016. Sample collected using purposive sampling method. The total of 33 companies were determined as sample during 2014-2016. The method of analysis of this research using multiple linier regresssion. The result showed that investment opportunity set and profitability has positive influence to the firm value, and capital structure and liquidity has no effect on the firm value. While the size of firm as a control variable has significant positive influence to the firm value.
\end{abstract}

\begin{abstract}
A B S T R A K
Penelitian ini bertujuan untuk memperoleh bukti empiris tentang penentu nilai properti dan real estate dalam periode pembangunan infrastruktur yang tak hentihentinya. Variabel independen yang digunakan dalam penelitian ini adalah struktur modal yang diukur dengan rasio utang terhadap ekuitas (DER), peluang investasi yang diukur dengan rasio market to book (MBA), likuiditas yang diukur dengan rasio saat ini (CR), dan profitabilitas yang diukur dengan return on equity ( KI$J A N G)$. Variabel dependen adalah nilai perusahaan yang diukur dengan harga ke nilai buku (PBV). Variabel kontrol adalah ukuran perusahaan. Populasi yang digunakan dalam penelitian ini adalah perusahaan properti dan real estate yang terdaftar di Bursa Efek Indonesia pada periode 2014-2016. Sampel dikumpulkan dengan menggunakan metode purposive sampling. Total 33 perusahaan ditentukan sebagai sampel selama 2014-2016. Metode analisis penelitian ini menggunakan regresi linier berganda. Hasil penelitian menunjukkan bahwa set kesempatan investasi dan profitabilitas memiliki pengaruh positif terhadap nilai perusahaan, dan struktur modal dan likuiditas tidak berpengaruh terhadap nilai perusahaan. Sedangkan ukuran perusahaan sebagai variabel kontrol memiliki pengaruh positif signifikan terhadap nilai perusahaan.
\end{abstract}

\section{PENDAHULUAN}

Harga saham sering diidentifikasikan dengan nilai perusahaan. Pada penutupan perdagangan saham Rabu, 17 Mei 2017 pukul 16.00 WIB terdapat fenomena Indeks Harga Saham Gabungan (IHSG) terpuruk akibat pelemahan dari delapan sektor, salah satunya sektor yang ditutup menurun tajam yaitu sektor properti sebesar $-1,21 \%$ dengan rincian saham-saham yang mengalami persentase penurunan terbesar yaitu emiten properti BSDE (-
5,82\%), PWON $(-5 \%), \quad$ SMRA

$(-4,21 \%)$

(Kompas.com).

Nilai perusahaan menurut Brigham dan Houston (2014) juga dapat dilihat dari Price to Book Ratio (PBV) yaitu semakin tinggi nilai rasio PBV maka semakin tinggi penilaian investor, sehingga semakin besar pula peluang para investor untuk membeli saham perusahaan tersebut. Berdasarkan data keuangan dan rasio dalam IDX Fact Book 2017 menunjukkan bahwa pada periode tahun 2014 
sampai dengan 2016 PBV sektor properti dan real estate terus mengalami penurunan. Pada tahun 2014 PBV sektor properti dan real estate sebesar 1,86 kemudian pada tahun 2015 menurun menjadi 1,65 dan pada tahun 2016 kembali mengalami penurunan sehingga menjadi 1,54.

Teori sinyal yang dikembangkan oleh Ross (1977) memandang bahwa untuk meningkatkan saham perusahaanya, maka pihak eksekutif perusahaan dalam hal ini manajemen perusahaan terdorong untuk menyampaikan informasi kepada calon investor. Informasi ini merupakan sinyal yang dikirim kepada calon investor berupa laporan keuangan. Salah satu sinyal yang diberikan dalam laporan keuangan yaitu struktur modal perusahaan. Struktur modal adalah perimbangan antara penggunaan modal pinjaman dengan modal sendiri (Sjahrial, 2014). Sjahrial (2014), menyatakan bahwa berdasarkan teori sinyal, suatu penawaran hutang diterima sebagai suatu pertanda positif. Trade off theory memandang bahwa perusahaan menukar manfaat pajak yang diperoleh dari penggunaan hutang dengan masalah yang timbul akibat dari penggunaan hutang yaitu potensi kebangkrutan (Brigham dan Houston, 2014). Sjahrial (2014), menyatakan bahwa manajer keuangan sebagai pimpinan perusahaan harus dapat mencari bauran pendanaan yang tepat agar tercapai struktur modal yang optimal, dimana struktur modal yang optimal secara langsung akan mempengaruhi nilai perusahaan.

Selain itu, Myers (1977) menyatakan bahwa investment opportunity set akan memberikan suatu petunjuk yang lebih luas, dimana pengeluaran yang dilakukan perusahaan di masa depan ini akan berdampak pada nilai perusahaan. Investment opportunity set merupakan kombinasi yang dilakukan oleh perusahaan terhadap aktiva yang dimilikinya dan pilihan investasi perusahaan di masa mendatang dengan net present value positif (Myers, 1977).

Faktor lain yang dapat mempengaruhi nilai perusahaan yaitu likuiditas perusahaan, dimana likuiditas merupakan rasio yang digunakan untuk mengukur sampai seberapa jauh tingkat kemampuan perusahaan melunasi kewajiban jangka pendeknya yang akan segera jatuh tempo (Hery, 2015). Perusahaan dikatakan likuid jika perusahaan tersebut memiliki kemampuan untuk melunasi kewajiban jangka pendeknya pada saat jatuh tempo, begitu juga sebaliknya (Hery, 2015). Selanjutnya, profitabilitas juga dapat mempengaruhi nilai perusahaan, dimana profitabilitas merupakan rasio yang digunakan untuk mengukur kemampuan perusahaan dalam menghasilkan laba dari aktivitas normal bisnis perusahaan tersebut (Hery, 2015).

Uzliawati dkk. (2016), melakukan penelitian yang hasilnya struktur modal berpengaruh positif terhadap nilai perusahaan. Hasil penelitian ini didukung oleh hasil penelitian yang dilakukan Safitri dan Wahyuati (2015), Deli dan Kurnia (2017) serta Indasari dan Yadnyana (2018). Namun, hasil penelitian ini tidak sejalan dengan hasil penelitian Ernawati dan Widyawati (2015), Novari dan Lestari (2016) serta Lubis dkk. (2017). Selain itu, Uzliawati dkk. (2016) melakukan penelitian yang hasilnya juga didukung oleh penelitian Safitri dan Wahyuati (2015) yaitu investment opportunity set berpengaruh positif terhadap nilai perusahaan. Uzliawati dkk. (2016) dalam penelitiannya menjadikan ukuran perusahaan sebagai variabel kontrol yang hasilnya menunjukkan bahwa ukuran perusahaan berpengaruh positif terhadap nilai perusahaan. Hasil ini didukung oleh penelitian Ernawati dan Widyawati (2015) serta Novari dan Lestari (2016).

Lubis dkk. (2017), melakukan penelitian yang hasilnya menunjukkan bahwa profitabilitas berpengaruh positif terhadap nilai perusahaan. Hasil penelitian ini didukung oleh penelitian yang dilakukan Ernawati dan Widyawati (2015), Novari dan Lestari (2016), Deli dan Kurnia (2017) serta Indasari dan Yadnyana (2018). Namun, hasil penelitian ini tidak sejalan dengan hasil penelitian Safitri dan Wahyuati (2015). Selain itu, hasil penelitian Lubis dkk (2017) tidak sejalan dengan hasil penelitian yang dilakukan oleh Deli dan Kurnia (2017) yang menunjukkan hasil bahwa likuiditas berpengaruh positif terhadap nilai perusahaan. Namun, hasil penelitian ini didukung oleh penelitian yang dilakukan Uzliawati dkk (2016) serta Indasari dan Yadnyana (2017).

Penelitian ini mengacu pada penelitian Uzliawati dkk (2016) dan Lubis dkk (2017). Variabel penelitian dalam penelitian ini adalah variabel independen yang meliputi struktur modal, investment opportunity set, likuiditas, dan profitabilitas, sedangkan variabel dependen dalam penelitian ini adalah nilai perusahaan serta ukuran perusahaan digunakan sebagai variabel kontrol dalam penelitian ini.

Objek penelitian dan periode penelitian ini berbeda dengan penelitian sebelumnya yaitu dalam penelitian ini menggunakan Perusahaan Properti dan Real Estate yang Terdaftar di BEI sebagai objek penelitian dengan periode penelitian yang dilakukan selama 3 tahun yaitu tahun 2014-2016. Alasan penelitian ini menggunakan Perusahaan Properti dan Real Estate yang Terdaftar di BEI se- 
bagai objek penelitian dengan periode penelitian yang dilakukan selama 3 tahun yaitu tahun 20142016 karena berdasarkan data IDX Fact Book 2017 yang telah dijelaskan diatas yaitu sektor properti terus mengalami penurunan PBV. Di sisi lain, pada tahun 2014 merupakan tahun pembangunan infrastruktur. Dimana menurut Menteri Perhubungan, Budi Karya Sumadi, dengan adanya gencarnya proyek infrastruktur ini sektor properti akan ikut tumbuh (Okezone.com). Namun, pada kenyataannya di tengah gencarnya pembangunan infrastruktur saat ini, saham properti justru mengalami penurunan sehingga menyebabkan nilai perusahaan sektor properti yang diukur dengan PBV terus mengalami penurunan.

\section{KAJIAN LITERATUR DAN PENGEMBANGAN HIPOTESIS}

\section{Teori Sinyal (Signalling Theory)}

Teori sinyal dicetuskan oleh Spence (1977) yang menyatakan bahwa manajemen memberikan sinyal kepada investor berupa informasi yang relevan, kemudian investor tersebut mengambil sebuah keputusan berdasarkan sinyal yang telah diterima. Teori ini dikembangkan kembali oleh Ross (1977) yang menjelaskan bahwa dorongan pihak eksekutif perusahaan dalam hal ini mananajeman perusahaan meyampaikan informasi kepada calon investor agar saham perusahaannya mengalami peningkatan. Menurut Brigham dan Houston (2001), isyarat atau sinyal adalah petunjuk yang diberikan perusahaan kepada investor mengenai bagaimana pandangan manajemen terhadap prospek perusahaan, dimana sinyal ini berupa informasi realisasi keinginan pemilik perusahaan yang telah diwujudkan oleh manajemen.

Menurut Fahmi (2014), signaling theory adalah teori yang membahas mengenai naik dan turunnya harga di pasar sehingga mempengaruhi keputusan investor, seperti naik turunnya harga saham, obligasi dan sebagainya. Kondisi pasar sangat dipengaruhi oleh reaksi investor dalam menanggapi sinyal positif dan sinyal negatif. Asumsi dasar teori sinyal ini yaitu investor akan menangkap sinyal yang diberikan oleh perusahaan, kemudian investor akan bereaksi dalam menanggapi sinyal tersebut sesuai dengan pemahamannya terhadap sinyal yang telah diberikan oleh perusahaan, dimana hal ini berkaitan dengan nilai perusahaan. Akibatnya ketika sinyal yang diberikan oleh perusahaan berupa informasi struktur modal, investment opportunity set, likuiditas, dan profitabilitas menunjukkan nilai yang berubah, maka hal ini dapat memberikan informasi kepada investor dalam memberikan penilaian terhadap nilai perusahaan.

\section{Trade Off Theory}

Trade off theory merupakan teori struktur modal yang menyatakan bahwa perusahaan menukar manfaat pajak dari pendanaan utang dengan masalah yang ditimbulkan oleh potensi kebangkrutan (Brigham dan Houston, 2014). Teori ini menyatakan bahwa manajer akan berusaha meningkatkan utang sampai pada suatu titik, dimana manfaat pajak yang diperoleh perusahaan dari penggunaan utang seimbang dengan biaya yang timbul akibat dari penggunaan utang, titik inilah yang disebut struktur modal yang optimal. Struktur modal yang optimal adalah struktur modal yang mengoptimalkan keseimbangan antara risiko dan pengembalian sehingga memaksimumkan harga saham (Weston dan Brigham, 1999). Brigham dan Houston (2014), menyatakan bahwa trade off theory merupakan teori struktur modal, dimana perusahaan menukar manfaat dari pendaan hutang dengan masalah yang ditimbulkan oleh potensi kebangkrutan.

\section{Nilai Perusahaan}

Nilai perusahaan adalah harga yang bersedia dibayar oleh calon pembeli apabila perusahaan tersebut dijual (Husnan dan Pudjiastuti, 2002). Sudana (2015) menyatakan bahwa nilai pasar saham perusahaan mencerminkan nilai perusahaan, dimana jika nilai perusahaan turun maka nilai pasar saham juga akan turun dan begitu juga sebaliknya. Brigham dan Houston (2014), menyatakan bahwa rasio nilai pasar berhubungan dengan harga saham perusahaan, dimana rasio pasar ini memberikan indikasi bagi manajemen tentang bagaimana pandangan investor terhadap risiko dan prospek perusahaan di masa depan.

\section{Struktur Modal}

Struktur modal merupakan perimbangan antara penggunaan modal pinjaman yang terdiri dari hutang jangka pendek yang bersifat permanen, hutang jangka panjang dengan modal sendiri yang terdiri dari saham preferen dan saham biasa (Sjahrial, 2014). Manajer keuangan sebagai pimpinan perusahaan harus dapat mencari bauran pendanaan yang tepat agar tercapai struktur modal yang optimal, dimana struktur modal yang optimal secara langsung akan mempengaruhi nilai perusahaan (Sjahrial, 2014).

Brigham dan Houston (2011), menyatakan bahwa struktur modal optimal merupakan struktur 
modal perusahaan yang akan memaksimalkan harga sahamnya. Perusahaan pada umumnya menganalisis sejumlah faktor, dan kemudian menetapkan suatu sasaran struktur modal, dimana sasaran ini dapat berubah dari waktu ke waktu seiring dengan perubahan kondisi, tetapi pada satu waktu manejemen biasanya memiliki satu struktur spesifik yang menjadi acuan (Brigham dan Houston 2011)

\section{Invesment Opportunity Set}

Investment opportunity set adalah kombinasi yang dilakukan oleh perusahaan terhadap aktiva yang dimilikinya dan pilihan investasi perusahaan di masa mendatang dengan net present value positif (Myers, 1977). Sehingga pengeluaran yang dilakukan perusahaan di masa depan ini akan berdampak pada nilai perusahaan, maka dapat disimpulkan bahwa investment opportunity set ini akan memberikan suatu petunjuk yang luas.

\section{Likuiditas}

Likuiditas merupakan rasio yang digunakan untuk mengukur sampai seberapa jauh tingkat kemampuan perusahaan dalam melunasi kewajiban jangka pendeknya yang akan segera jatuh tempo (Hery, 2015). Menurut Kasmir (2006), ada beberapa faktor yang dapat menyebabkan perusahaan tidak mampu untuk membayar kewajibannya terutama hutang yang sudah jatuh tempo yaitu pertama, bisa dikarenakan memang perusahaan sedang tidak memiliki dana sama sekali, atau kedua bisa mungkin saja perusahaan memiliki dana, tetapi saat jatuh tempo perusahaan tidak memilki dana yang cukup secara tunai sehingga harus menunggu dalam waktu tertentu untuk mencairkan aktiva lainnya untuk membayar kewajibannya yang telah jatuh tempo tersebut seperti dengan menagih piutang, menjual suratsurat berharga, atau menjual sediaan atau aktiva lainnya

\section{Profitabilitas}

Profitabilitas adalah rasio yang digunakan untuk mengukur kemampuan perusahaan dalam menghasilkan laba dari aktivitas normal bisnisnya (Hery, 2015). Sedangkan Brigham dan Houston (2014) menyatakan bahwa profitabilitas merupakan hasil akhir dari seluruh kebijakan keuangan dan keputusan operasional suatu perusahaan.

\section{$\underline{\text { Hipotesis }}$}

$\mathrm{H}_{1}$ : Struktur modal berpengaruh positif terhadap nilai perusahaan
$\mathrm{H}_{2}$ : Investment opportunity set berpengaruh positif terhadap niali perusahaan

$\mathrm{H}_{3}$ : Likuiditas berpengaruh positif terhadap nilai perusahaan

$\mathrm{H}_{4}$ : Profitabilitas berpengaruh positif terhadap nilai perusahaan

\section{$\underline{\text { Rerangka Penelitian }}$}

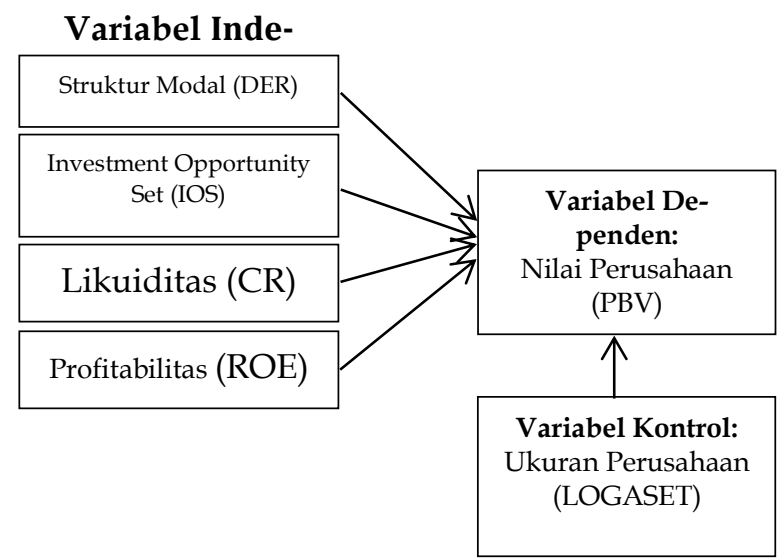

\section{Gambar 1 Rerangka Penelitian}

\section{METODE PENELITIAN}

Pendekatan penlitian yang digunakan dalam penelitian ini adalah pendekatan kuantitatif. Populasi dalam penelitian ini perusahaan sektor properti dan real estate yang terdaftar di Bursa Efek Indonesia tahun 2014-2016. Sumber data dalam penelitian ini adalah data sekunder yang diambil dari alporan keuangan dan laporan kinerja perusahaan sampel yang diperoleh dari website http://www.idx.co.id.

Teknik pengambilan sampel dalam penelitian ini menggunakan sampling purposive. Sampling purposive adalah teknik penentuan sampel dengan pertimbangan tertentu (Sugiyono, 2015). Pertimbangan pemilihan sampel dalam penelitian ini adalah:

1) Perusahaan sektor properti dan real estate yang konsisten terdaftar di Bursa Efek Indonesia pada periode tahun 2014 sampai dengan tahun 2016.

2) Perusahaan yang menerbitkan laporan keuangan untuk periode yang berakhir pada 31 Desember selama periode tahun 2014 sampai dengan tahun 2016.

3) Perusahaan yang memilki laba positif selama periode tahun 2014 sampai dengan tahun 2016.

4) Perusahaan yang menggunakan mata uang rupiah dalam pelaporan keuangannya. 
Total perusahaan yang terpilih memenuhi kriteria dalam pengambilan sampel sebanyak 33 perusahaan.

Tabel 1. Penentuan Sampel Berdasarkan Kriteria

\begin{tabular}{|l|c|}
\hline \multicolumn{1}{|c|}{ Keterangan } & Jumlah \\
\hline $\begin{array}{l}\text { Perusahaan sektor properti dan real } \\
\text { estate yang konsisten terdaftar di } \\
\text { Bursa Efek Indonesia periode 2014- } \\
\text { 2016 yang }\end{array}$ & 42 \\
\hline $\begin{array}{l}\text { Perusahaan laporan keuangan } \\
\text { mempublikasikan } \\
\text { selama periode 2014-2016 }\end{array}$ & $(1)$ \\
\hline $\begin{array}{l}\text { Perusahaan yang tidak memilki laba } \\
\text { positif selama periode 2014-2016 }\end{array}$ & $(8)$ \\
\hline $\begin{array}{l}\text { Perusahaan yang tidak menggunakan } \\
\text { mata uang rupiah dalam pelaporan } \\
\text { keuangannya }\end{array}$ & 0 \\
\hline $\begin{array}{l}\text { Perusahaan yang terpilih menjadi } \\
\text { sampel }\end{array}$ & \\
\hline $\begin{array}{l}\text { Jumlah total sampel selama } 3 \text { tahun } \\
\text { Data outlier }\end{array}$ & \\
\hline
\end{tabular}

\section{Operasionalisasi Variabel}

\section{Variabel Independen}

Berikut merupakan variabel independen beserta pengukurannnya dalam penelitian ini:

1. Struktur Modal $(\mathrm{DER})=$ Total Debt/Total Equity (Subramanyam dan Wild, 2014)

2. Investment Opportunity Set $(\mathrm{MBA})=[$ Nilai buku hutang + (Jumlah lembar saham beredar $\mathrm{x}$ harga saham penutupan)]/Total Aset (Myers, 1977)

3. Likuiditas $(\mathrm{CR})=$ Aktiva Lancar/Hutang Lancar (Brigham dan Houston, 2014)

4. Profitabilitas $(\mathrm{ROE})=$ Laba bersih/Total Ekuitas (Brigham dan Houston, 2014)

Struktur modal dalam penelitian ini diukur menggunakan Debt to Equity Ratio (DER). Penelitian ini menggunakan DER sebagai pengukuran struktur modal karena DER dapat menunjukkan seberapa besar kemampuan perusahaan untuk membayar hutang yang dimilikinya baik hutang jangka pendek maupun jangka panjang dengan modal yang dimiliki perusahaan. Investment opportunity set dalam penelitian ini diukur menggunakan Market to Book Asset Ratio (MBA). Penelitian ini menggunakan MBA sebagai pengukuran investment opportunity set karena didasari pemikiran bahwa perusahaan yang memiliki pertumbuhan tinggi akan memiliki nilai pasar yang lebih tinggi secara relatif dari aktivaaktiva yang dimiliki (assets in place).

Likuiditas dalam penelitian ini diukur menggunakan current ratio (CR). Penelitian ini menggunakan current ratio (CR) sebagai pengukuran likuiditas karena selain dapat menunjukkan kemampuan perusahaan dalam menyelesaikan kewajiban jangka pendeknya, current ratio juga dapat menunjukkan adanya indikasi masalah dalam perusahaan ketika perusahaan memiliki current ratio yang terlalu tinggi, seperti penumpukan persediaan dan banyaknya piutang yang tidak tertagih. Profitabilitas dalam penelitian ini diukur menggunakan Return on Equity (ROE). Penelitian ini menggunakan ROE sebagai pengukuran profitabilitas karena ROE merupakan pengukuran profitabilitas yang dipandang dari sudut pandang pemegang saham, dimana ROE menggambarkan seberapa besar tingkat pengembalian (return) yang akan diterima oleh pemegang saham atas modal yang diinventasikan.

\section{Variabel Dependen}

Variabel dependen dalam penelitian ini adalah nilai perusahaan $(\mathrm{PBV})=$ Harga pasar saham/Nilai buku per lembar saham (Brigham dan Houston, 2014).

Nilai perusahaan dalam penelitian ini diukur menggunakan Price to Book Value (PBV). Penelitian ini menggunakan PBV sebagai pengukuran nilai perusahaan karena (1) Nilai buku sifatnya relatif stabil. Bagi investor yang kurang percaya terhadap estimasi arus kas, maka nilai buku merupakan cara yang paling sederhana untuk membandingkannya. (2) Adanya praktik akuntansi yang relatif standar diantara perusahaan-perusahaan menyebabkan PBV dapat dibandingkan antar berbagai perusahaan yang akhirnya dapat memberikan signal apakah nilai perusahaan under atau overvaluation. (3) Pada kasus perusahaan yang memilki earnings negatif tidak memungkinkan untuk menggunakan PER, sehingga penggunaan 
PBV dapat menutupi kelemahan PER (Murhadi, 2009).

\section{Variabel Kontrol}

Variabel kontrol dalam penelitian ini adalah ukuran perusahaan $($ LOGASET $)=$ Log Total Aset

\section{$\underline{\text { Teknik Analisis Data }}$}

\section{Uji Normalitas}

Uji normalitas dilakukan untuk menguji apakah dalam model regresi, variabel pengganggu atau residual memiliki distribusi normal (Ghozali, 2016). Pengujian normalitas dalam penelitian ini dilakukan dengan menggunakan metode uji statistik Kolmogorov-Smirnov. Tingkat kesalahan (a) yang ditetapkan adalah sebesar 5\%. Ghozali (2016) menyatakan bahwa pengujian normalitas dilakukan dengan melihat nilai asymp. Sig (2tailed). Apabila nilai asymp. Sig (2-tailed >0,05 maka disimpulkan bahwa data berdistribusi normal, begitu juga sebaliknya.

2. Uji Autokorelasi

Uji autokorelasi dilakukan untuk menguji apakah dalam model regresi linear ada korelasi antara kesalahan pengganggu pada periode $t$ dengan kesalahan pengganggu pada periode t-1 atau sebelumnya (Ghozali, 2016). Pengujian autokorelasi pada penelitian ini dilakukan dengan menggunakan menggunakan uji Durbin-Watson (DW test).

\section{Uji Mutikoliniearitas}

Menurut Ghozali (2016), uji multikolinieritas bertujuan untuk menguji apakah model regresi ditemukan adanya korelasi antar variabel bebas (independen). Pengujian multikoliniearitas pada penelitian ini dilakukan dengan melihat nilai tolerance dan Variance Inflation Factor (VIF).

\section{Uji Regresi Linier Berganda}

Uji regresi linier berganda yang digunakan untuk menguji pengaruh lebih dari satu variabel bebas terhadap satu variabel terikat. Adapun model regresi linear beganda dalam penelitian ini dapat dirumuskan sebagai berikut:

$\mathrm{PBV}=\alpha+\beta 1 \mathrm{DER}+\beta 2 \mathrm{MBA}+\beta 3 \mathrm{CR}+\beta 4 \mathrm{ROE}+$ $\beta 5$ LOGASET $+\mathrm{e}$

Dimana:

$$
\begin{array}{ll}
\text { PBV } & =\text { Nilai perusahaan } \\
\text { DER } & =\text { Struktur modal } \\
\text { MBA } & =\text { Investment Opportunity Set } \\
\text { CR } & =\text { Likuiditas } \\
\text { ROE } & =\text { Profitabilitas } \\
\text { LOGASET } & =\text { Ukuran perusahaan } \\
\alpha & =\text { Intercept model regresi }
\end{array}
$$

$$
\begin{array}{ll}
\beta & =\text { Koefisien model regresi } \\
\mathrm{E} & =\text { NILAI ERROR }
\end{array}
$$

\section{HASIL DAN PEMBAHASAN}

Pengujian statistik deskriptif dalam penelitian ini digunakan untuk memberikan gambaran atau deskripsi data yang digunakan dalam penelitian. Variabel yang digunakan dalam penelitian ini yaitu nilai perusahaan, struktur modal, investment opportunity set, likuiditas, profitabilitas, dan ukuran perusahaan. Dari hasil pengujian statistik deskriptif atas satu variabel dependen, empat variabel independen, dan satu variabel kontrol, maka diperoleh hasil statistik deskriptif pada tabel 2 berikut ini:

Tabel 2. Statistik Deskriptif

\begin{tabular}{|l|c|r|r|r|r|}
\hline & N & \multicolumn{1}{|c|}{ Min } & \multicolumn{1}{c|}{ Mak } & \multicolumn{1}{c|}{ Mean } & $\begin{array}{c}\text { Std. } \\
\text { Deviation }\end{array}$ \\
\hline PBV & 99 & 0,150 & 8,300 & 1,81010 & 1,762476 \\
\hline DER & 99 & 0,074 & 1,834 & 0,73140 & 0,438398 \\
\hline MBA & 99 & 0,213 & 5,549 & 1,42521 & 1,039126 \\
\hline CR & 99 & 0,562 & 8,801 & 2,25609 & 1,527802 \\
\hline ROE & 99 & 0,001 & 0,412 & 0,11701 & 0,087727 \\
\hline $\begin{array}{l}\text { LOG } \\
\text { ASET }\end{array}$ & 99 & 11,245 & 13,659 & 12,66198 & 0,567524 \\
\hline $\begin{array}{l}\text { Valid } \\
\text { N }\end{array}$ & 99 & & & & \\
\hline
\end{tabular}

Pada awal proses pengolahan data, dari 99 data observasi terdapat 2 data outlier, sehingga 2 data outlier tersebut harus dikeluarkan dari analisis dalam penelitian ini. Menurut Ghozali (2016), outlier adalah kasus atau data yang memiliki karakteristik unik yang terlihat sangat berbeda jauh dari observasi-observasi lainnya dan muncul dalam bentuk nilai ekstrim baik untuk sebuah variabel tunggal atau variabel kombinasi. Setelah dilakukan pembuangan data outlier jumlah data yang diobservasi menjadi 97. Berikut ini merupakan statistik deskriptif untuk data yang sudah dilakukan pengeluaran data outlier dalam penelitian ini:

\section{Hasil Uji Asumsi Klasik}

\section{Tabel 3. Statistik Deskriptif}

\begin{tabular}{|l|c|r|r|r|r|}
\hline & N & \multicolumn{1}{c|}{ Min } & \multicolumn{1}{c|}{ Mak } & \multicolumn{1}{c|}{ Mean } & \multicolumn{1}{c|}{$\begin{array}{c}\text { Std. } \\
\text { Deviation }\end{array}$} \\
\hline LN_PBV & 97 & $-1,90$ & 2,12 & 0,2280 & 0,88585 \\
\hline DER & 97 & 0,147 & 1,834 & 0,74484 & 0,432625 \\
\hline LN_MBA & 97 & $-1,15$ & 1,71 & 0,1796 & 0,59679 \\
\hline LN_CR & 97 & $-0,58$ & 1,93 & 0,6023 & 0,58783 \\
\hline ROE & 97 & 0,001 & 0,412 & 0,11701 & 0,087791 \\
\hline $\begin{array}{l}\text { LOG } \\
\text { ASET }\end{array}$ & 97 & 11,245 & 13,659 & 12,65835 & 0,572832 \\
\hline Valid N & 97 & & & & \\
\hline
\end{tabular}

Pengujian asumsi klasik yang terdiri dari uji normalitas, uji autokorelasi, uji multikolineritas, dan uji heteroskedastisitas. Pengujian asumsi klasik dalam penelitian ini dilakukan sebelum 
dilakukannya pengujian masing-masing hipotesis.

\section{Uji Normalitas}

Uji normalitas digunakan untuk mengetahui apakah dalam regresi, residual atau variabel pengganggu terdistribusi secara normal. Uji normalitas dalam penelitian ini menggunakan uji statistik Kolmogorov Smirnov. Berikut merupakan hasil uji statistik Kolmogorov Smirnov:

Tabel 4. Hasil Uji Kolmogorov Smirnov

\begin{tabular}{|l|r|l|}
\hline & \multicolumn{1}{|c|}{$\begin{array}{c}\text { Unstandardized } \\
\text { Residual }\end{array}$} & Ket \\
\hline $\mathrm{N}$ & 97 & \\
\hline $\begin{array}{l}\text { Kolmogorov-Smirnov } \\
\mathrm{Z}\end{array}$ & 0,888 & \\
\hline Asymp. Sig. (2-tailed) & 0,409 & $>0,05$ \\
\hline
\end{tabular}

Hasil uji Kolmogorov Smirnov diperoleh nilai sebesar 0,888 dengan probabilitas signifikansi (Asymp. Sig) sebesar 0,409. Nilai asymp. sig menunjukkan >0,05 hal ini menunjukkan bahwa data residual terdistribusi normal atau memenuhi asumsi normalitas. Berdasarkan hasil uji Kolmogorov Smirnov ini dapat disimpulkan bahwa data yang digunakan dalam penelitian ini terdistribusi normal.

\section{Uji Autokorelasi}

Uji Autokorelasi digunakan untuk mengetahui apakah dalam suatu regresi linear terdapat hubungan antara kesalahan pengganggu pada periode $\mathrm{t}$ dengan periode sebelumnya ( $\mathrm{t}-1)$. Model regresi yang baik adalah yang bebas dari autokorelasi. Hasil pengujian autokorelasi dapat dilihat pada tabel 5 berikut:

Tabel 5. Hasil Uji Durbin Watson

\begin{tabular}{|c|c|c|}
\hline Model & Durbin Watson & Keterangan \\
\hline PBV & 2,000 & $\begin{array}{l}\text { Tidak terjadi } \\
\text { autokorelasi }\end{array}$ \\
\hline
\end{tabular}

Berdasarkan tabel 5, menunjukkan bahwa nilai DW menunjukkan sebesar 2,000 lebih besar dari nilai (dU) 1,7795 dan lebih kecil dari 4 - 1,7795 (4dU). Maka dapat disimpulkan bahwa bebas dari autokorelasi.

\section{Uji Multikolinieritas}

Uji multikolinearitas digunakan untuk menguji apakah dalam model regresi terdapat korelasi antar variabel independen. Ada tidaknya multikolinearitas dapat diketahui dari nilai tolerance dan nilai VIF. Model regresi dinyatakan bebas dari multikolineritas apabila nilai tolerance diatas 0,10 dan nilai VIF dibawah 10. Model regresi yang baik adalah model regresi yang tidak terdapat korelasi diantara variabel independen. Hasil uji multikolinieritas pada penelitian dapat dilihat pada tabel 6 berikut

\section{Tabel 6. Hasil Uji Multikolinieritas}

\begin{tabular}{|c|c|c|c|}
\hline Model & Tolerance & VIF & Keterangan \\
\hline DER & 0,640 & 1,563 & $\begin{array}{c}\text { Tidak terjadi } \\
\text { multikolinieritas }\end{array}$ \\
\hline LN_MBA & 0,698 & 1,432 & $\begin{array}{c}\text { Tidak terjadi } \\
\text { multikolinieritas }\end{array}$ \\
\hline LN_CR & 0,867 & 1,153 & $\begin{array}{c}\text { Tidak terjadi } \\
\text { multikolinieritas }\end{array}$ \\
\hline ROE & 0,708 & 1,413 & $\begin{array}{c}\text { Tidak terjadi } \\
\text { multikolinieritas }\end{array}$ \\
\hline LOGASET & 0,687 & 1,456 & $\begin{array}{c}\text { Tidak terjadi } \\
\text { multikolinieritas }\end{array}$ \\
\hline
\end{tabular}

Pada tabel 6 menunjukkan bahwa tidak ada satupun varibel independen yang memiliki nilai tolerance dibawah 0,10 dan nilai VIF diatas 10. Maka dapat disimpulkan bahwa antar variabel independen tidak terdapat korelasi, karena nilai tolerance dari $\mathrm{DER}=0,640>0,10, \mathrm{MBA}=0,698>$ $0,10, \mathrm{CR}=0,867>0,10, \mathrm{ROE}=0,708>0,10, \mathrm{LOG}$ ASET $=0,687>0,10$ dan nilai VIF DER $=1,563<10$, $\mathrm{MBA}=1,432<10, \mathrm{CR}=1,153<10, \mathrm{ROE}=1,413<10$, LOG ASET $=1,456<10$. Jadi dapat disimpulkan bahwa dalam penelitian ini tidak terjadi multikolinearitas antara variabel dalam model regresi.

\section{Uji Heteroskedastisitas}

Uji heteroskedastisitas bertujuan untuk menguji apakah dalam model regresi terjadi ketidaksamaan variance dari residual satu pengamatan ke pengamatan lain (Ghozali, 2016). Model regresi yang baik adalah model yang homoskedastisitas atau tidak terjadi heteroskedastisitas.

$$
\text { Untuk mendeteksi ada tidaknya }
$$
heteroskedastisitas dalam penelitian ini, dilakukan menggunakan uji glejser. Berikut merupakan hasil uji heteroskedastisitas dalam penelitian ini: 
Tabel 7. Hasil Uji Heteroskedastisitas dengan Uji Glejser

\begin{tabular}{|c|c|c|}
\hline Variabel & Sig. & Keterangan \\
\hline DER & 0,987 & $\begin{array}{c}\text { Tidak terjadi } \\
\text { heteroskedastisitas }\end{array}$ \\
\hline LN_MBA & 0,064 & $\begin{array}{c}\text { Tidak terjadi } \\
\text { heteroskedastisitas }\end{array}$ \\
\hline LN_CR & 0,071 & $\begin{array}{c}\text { Tidak terjadi } \\
\text { heteroskedastisitas }\end{array}$ \\
\hline ROE & 0,277 & $\begin{array}{c}\text { Tidak terjadi } \\
\text { heteroskedastisitas }\end{array}$ \\
\hline LOGASET & 0,208 & $\begin{array}{c}\text { Tidak terjadi } \\
\text { heteroskedastisitas }\end{array}$ \\
\hline
\end{tabular}

Berdasarkan tabel 7 menunjukkan bahwa variabel DER, MBA, CR, ROE dan LOGASET tidak ada satupun dari semua variabel tersebut diatas yang memiliki nilai probabilitas signifikansi dibawah nilai kepercayaan 0,05 . DER memiliki nilai signifikansi sebesar 0,987, MBA sebesar 0,064, CR sebesar 0,071, ROE sebesar 0,277, dan LOGASET sebesar 0,208 . Semua variabel memiliki nilai probabilitas diatas 0,05, maka dapat disimpulkan bahwa model regresi dalam penelitian ini tidak terjadi heteroskedastisitas.

\section{Uji Regresi Linier Berganda}

Metode analisis regresi linier berganda dalam penelitian ini digunakan untuk menguji pengaruh dari empat variabel independen yaitu struktur modal (DER), investment opportunity set (MBA), likuiditas (CR), profitabilitas (ROE), dan satu variabel kontrol yaitu ukuran perusahaan (LOGASET) terhadap satu variabel dependen yaitu nilai perusahaan (PBV). Berdasarkan perhitungan dari model regresi linear berganda, diperoleh hasil persamaan regresi yang dapat diketahui dalam tabel 8 berikut:

Tabel 8. Hasil Uji Regresi Linier Berganda

\begin{tabular}{|r|r|r|r|r|r|}
\hline Model & B & $\begin{array}{r}\text { Std. } \\
\text { Error }\end{array}$ & Beta & T & Sig \\
\hline (Constant) & $-1,313$ & 0,501 & & $-2,622$ & 0,010 \\
\hline DER & 0,054 & 0,057 & 0,026 & 0,946 & 0,347 \\
\hline LN_MBA & 1,358 & 0,040 & 0,915 & 34,300 & 0,000 \\
\hline LN_CR & 0,013 & 0,036 & 0,009 & 0,374 & 0,709 \\
\hline ROE & 0,923 & 0,267 & 0,092 & 3,453 & 0,001 \\
\hline LOGASET & 0,090 & 0,042 & 0,058 & 2,167 & 0,033 \\
\hline
\end{tabular}

Berdasarkan model regresi linier berganda pada tabel 8 di atas menunjukkan bahwa dari keempat variabel independen dan satu variabel kontrol yang dimasukkan ke dalam model regresi linier berganda, variabel DER dan CR tidak signifikan hal ini dapat dilihat dari nilai probabilitas untuk DER sebesar 0,347 dan CR sebesar 0,709 keduanya jauh diatas 0,05 . Sedangkan MBA, ROE, dan LOGASET memilki nilai probabilitas signifikan dibawah 0,05. Dari hasil ini dapat disimpulkan bahwa variabel PBV dipengaruhi oleh MBA, ROE, dan LOGASET dengan persamaan model regresi linier berganda sebagai berikut:

$\mathrm{PBV}=\alpha+\beta_{1} \mathrm{DER}+\beta_{2} \mathrm{MBA}+\beta_{3} \mathrm{CR}+\beta_{4} \mathrm{ROE}+$ $\beta_{5}$ LOGASET $+\mathrm{e}$

LN_PBV $=-1,313+0,054 \mathrm{DER}+1,358 \mathrm{LN} \_\mathrm{MBA}+$ 0,013LN_CR + 0,923ROE + 0,090LOGASET + e

Berdasarkan model regresi dari tabel 8 di atas maka hasil regresi berganda dapat dijelaskan sebagai berikut:

a. Persamaan regresi linear berganda di atas, diketahui mempunyai konstanta sebesar 1,313. Besaran konstanta tersebut menunjukkan bahwa jika variabel DER, MBA, CR, ROE, dan LOGASET diasumsikan konstan, maka variabel PBV sebesar -1,313.

b. Koefisien DER memiliki nilai sebesar 0,054 berarti setiap kenaikan DER sebesar satu satuan, maka akan meningkatkan PBV sebesar 0,054 .

c. Koefisien MBA memiliki nilai sebesar 1,358 berarti setiap kenaikan MBA sebesar satu satuan, maka akan meningkatkan PBV sebesar 1,358 .

d. Koefisien CR memiliki nilai sebesar 0,013 berarti setiap kenaikan CR sebesar satu satuan, maka akan meningkatkan PBV sebesar 0,013.

e. Koefisien ROE memiliki nilai sebesar 0,923 berarti setiap kenaikan ROE sebesar satu satuan, maka akan meningkatkan PBV sebesar 0,923 .

f. Koefisien LOGASET memiliki nilai sebesar 0,090 berarti setiap kenaikan LOGASET sebesar satu satuan, maka akan meningkatkan PBV sebesar 0,090.

Pembahasan

1. Pengaruh Struktur Modal Terhadap Nilai Perusahaan

Berdasarkan hasil uji signifikansi parsial (uji t) menunjukkan bahwa struktur modal (DER) tidak berpengaruh terhadap nilai 
perusahaan (PBV) yaitu nilai koefisien regresi positif sebesar 0,054 dengan nilai t-hitung $(0,946)$ lebih kecil dari t-tabel $(1.661)$, dan nilai signifikansi $(0,347)$ lebih besar dari 0,05 .

Tidak adanya pengaruh antara struktur modal dengan nilai perusahaan dalam penelitian ini karena adanya fenomena naiknya suku bunga. Berdasarkan Keputusan Rapat Dewan Gubernur (RDG) Bank Indonesia (BI) menaikkan suku bunga acuan atau BI rate sebesar 25 basis poin dari 7,5\% menjadi 7,75\% berdampak pada kenaikan suku bunga perbankan (sindonews.com). Adanya fenomena naiknya suku bunga ini, apabila investor meningkatkan jumlah hutangnya maka perusahaan akan jauh lebih besar menanggung biaya modal yaitu beban bunga. Investor akan merasa tidak aman berinvestasi pada sektor properti dan real estatesaat adanya fenomena naiknya suku bunga ini. Investor juga akan khawatir dengan pembayaran hutang beserta beban bunga perusahaan yang akan dijadikan tempat untuk berinvestasi.

Hasil penelitian ini tidak mendukung teori sinyal menurut Sjahrial (2014), dimana penawaran hutang dipandang sebagai pertanda positif yang menunjukkan prospek perusahaan bagus. Hasil penelitian ini juga tidak mendukung tradeoff theory yang menurut Sjahrial (2014), penggunaan hutang akan meningkatkan nilai perusahaan sampai titik struktur modal yang optimal.

Hasil penelitian ini tidak sejalan dengan penelitian Safitri dan Wahyuati (2015), Uzliawati dkk. (2016), Deli dan Kurnia (2017), serta Indasari dan Yadnyana (2018). Namun, hasil penelitian ini didukung oleh penelitian Ernawati dan Widyawati (2015), Novari dan Lestari (2016), serta Lubis dkk. (2017).

2. Pengaruh Investment Opportunity Set Terhadap Nilai Perusahaan

Berdasarkan hasil uji signifikansi parsial (uji t) menunjukkan bahwa investment opportunity setberpengaruh positif terhadap nilai perusahaan yaitu nilai koefisien regresi positif sebesar 1,358 dengan t-hitung $(34,300)$ lebih besar dari ttabel(1.661), dan nilai signifikansi $(0,000)$ lebih kecil dari 0,05 .

Hasil penelitian ini mendukung teori sinyal menurut Myers (1977), dimana investment opportunity set merupakan sinyal positif yang diberikan oleh perusahaan yaitu perusahaan memiliki prospek perusahaan yang bagus, sehingga berinvestasi pada perusahaan tersebut akan menghasilkan return yang tinggi. Hasil penelitian ini mendukung penelitian yang dilakukan Safitri dan Wahyuati (2015) serta Uzliawati dkk. (2016).

3. Pengaruh Likuiditas Terhadap Nilai Perusahaan Berdasarkan uji signifikansi parsial (uji t) menunjukkan bahwa likuiditas tidak berpengaruh terhadap nilai perusahaan yaitu nilai koefisien regresi positif sebesar 0,013 dengan nilai t-hitung $(0,374)$ lebih kecil dari nilai t-tabel $(1.661)$, dan nilai signifikansi $(0,709)$ lebih besar dari 0,05.

Tidak adanya pengaruh antara likuiditas dengan nilai perusahaan ini dimungkinkan karena investor tidak menghiraukan tingkat current ratio perusahaan karena investor menganggap bahwa perusahaan yang memiliki aset lancar yang tinggi, justru mengindikasikan aset lancar perusahaan tersebut tidak digunakan secara efisien atau menganggur.

Hasil penelitian ini tidak mendukung teori sinyal sebagaimana penelitian Deli dan Kurnia (2017) yang menyatakan bahwa tingkat likuiditas yang tinggi akan direspon positif oleh pihak luar perusahaan karena perusahaan dianggap mampu memenuhi kewajiban jangka pendeknya

4. Pengaruh Profitabilitas Terhadap Nilai Perusahaan

Berdasarkan uji signifikansi parsial (uji t) menunjukkan bahwa profitabilitas berpengaruh positif terhadap nilai perusahaan yaitu nilai koefisien regresi positif sebesar 0,923 dengan nilai t-hitung $(3,453)$ lebih besar dari t-tabel (1.661), dan nilai signifikansi $(0,001)$ lebih kecil dari 0,05 .

Hasil penelitian ini mendukung teori sinyal sebagaimana hasil penelitian Lubis dkk (2017) yang menyatakan bahwa profitabilitas yang tinggi merupakan sinyal baik yang dikirim oleh perusahaan kepada investor, dimana hal ini menunjukkan bahwa prospek perusahaan bagus sehingga nilai perusahaan akan meningkat.

5. Pengaruh Variabel Kontrol Terhadap Nilai Perusahaan

Ukuran perusahaan sebagai variabel kontrol dalam penelitian ini memiliki nilai koefisien regresi positif sebesar 0,090 dengan nilai t-hitung $(2,167)$ lebih besar dari t-tabel (1.661), dan nilai signifikansi $(0,033)$ lebih kecil dari 0,05 . Hal ini menunjukkan bahwa ukuran perusahaan dalam penelitian ini dapat dijadikan variabel kontrol. 


\section{SIMPULAN}

Berdasarkan hasil penelitian dan pembahasan yang telah dijelaskan, maka simpulan dalam penelitian ini adalah (a) struktur modal tidak berpengaruh terhadap nilai perusahaan; (b) Investment opportunity set berpengaruh positif terhadap nilai perusahaan; (c) Likuiditas tidak berpengaruh terhadap nilai perusahaan dan (d) Profitabilitas berpengaruh positif terhadap nilai perusahaan.

Penelitian ini memilki keterbatasan yaitu terdapat data outlier yang harus dikeluarkan dari data observasi, sehingga jumlah sampel akhir observasi menjadi 97 data observasi. Berdasarkan simpulan dan keterbatasan dalam penelitian ini, maka dapat diberikan saran bagi calon investor yang ingin berinvestasi pada perusahaan sektor properti dan real estate akan lebih baik mempertimbangkan investment opportunity set dan profitabilitas perusahaan. Untuk penelitian selanjutnya, dapat menambah variabel independen lain yang diprediksi akan berpengaruh terhadap nilai perusahaan.

\section{REFERENCES}

Brigham, E. F. danHouston, J. F., (2001), Manajemen Keuangan Edisi 8 Buku 1, Jakarta: Erlangga

Dasar-Dasar Manajemen Keuangan Edisi 11 Buku 2, Jakarta: Salemba Empat

Dasar-Dasar Manajemen Keuangan Edisi 11 Buku 1, Jakarta: Salemba Empat

Deli, E. P. I. dan Kurnia, (2017), Pengaruh Struktur Modal, Profitabilitas, Growth Opportunity dan Likuiditas Terhadap Nilai Perusahaan, Jurnal Ilmu dan Riset Akuntansi, Vol. 6, No. 7

Ernawati, D. dan Widyawati, D., (2015), Pengaruh Profitabilitas, Leverage, dan Ukuran Perusahaan Terhadap Nilai Perusahaan. Jurnal Ilmu E Riset Akuntansi, Vol 4 No 4.

Fahmi, I., (2014), Manajemen Keuangan Perusahaan dan Pasar Modal, Jakarta: Mitra Wacana Media.

Ghozali, I., (2016), Aplikasi Analisis Multivariete dengan Program IBM SPSS 23. Cetakan VIII, Semarang: Badan Penerbit Universitas Diponegoro

Hery., (2015), Analisis Kinerja Manajemen, Jakarta: PT Grasindo

Husnan, S. dan E. Pudjiastuti. 2002. Dasar-Dasar Manajemen Keuangan. Yogyakarta: UPP AMP YKPN

Indasari, A. P. dan Yadnyana, I. K., (2018) Pengaruh Profitabilitas, Growth Opportunity, Likuiditas, dan Struktur Modal Pada Nilai Perusahaan. E-Jurnal Akuntansi Universitas
Udayana, Vol 22 No 1, page 714-746.

Kasmir. 2006. Analisis Laporan Keuangan. Jakarta: RajaGrafindo Persada

Kompas.https:/ / ekonomi.kompas.com/read/2017/ 05/17/163124026/8.sektor.melorot.ihsg.kemba li.terpuruk diakses pada 28 Januari 2018 pukul 18.22

Lubis, I. L., Sinaga, B. M. dan Sasongko, H., (2017), Pengaruh Profitabilitas, Struktur Modal, dan Likuiditas Terhadap Nilai Perusahaan. Jurnal Aplikasi Bisnis dan Manajemen, Vol. 3 No 3, September 2017

Murhadi, W. R., (2009), Analisis Saham Pendekatan Fundamental. Jakarta: PT Indeks

Myers, S. C., (1977), Determinants of Corporate Borrowing. Journal of Financial Economics 5.

Novari, P. M. dan Lestari, P. V., (2016) Pengaruh Ukuran Perusahaan, Leverage, dan Profitabilitas Terhadap Nilai Perusahaan Pada Sektor Properti dan Real Estate. E-Jurnal Manajemen Unud, Vol 5 No 9, page 5671-5694

Okezone.

https://economy.okezone.com/read/2017/11 /01/320/1806358/gencar-proyekinfrastruktur-menhub-bagus-untuk-masadepan diakses pada 21 Mei 2018 pukul 19.05

Ross, S. A., (1977) The Determination of Financial Structure: The Incentive Signalling Approach. The Bell Journal of Economics, Vol 8 No 1 (Spring, 1977), page 23-40.

Safitri, N dan Wahyuati, A., (2015), Pengaruh Struktur Modal dan Keputusan Investasi Terhadap Profitabilitas dan Nilai Perusahaan. Jurnal Ilmu dan Riset Manajemen, Vol 4 No 2.

Sindonews.

https://ekbis.sindonews.com/read/934160/3 4/bi-rate-naik-perbankan-naikkan-sukubunga-1417953232 diakses pada 21 Mei 2018 pukul 19.31

Sjahrial, D., (2014), Manajemen Keuangan Lanjutan Edisi Revisi, Jakarta: Mitra Wacana Media

Spence, M., (1973), Job Marketing Signalling, The Quarterly Journal of economics, Vol 87 No 3.

Subramanyam, K.R. dan Wild, J. J., (2014), Financial Statement Analysis. Edisi 10. New Work: McGraw Hill

Sudana, I. M., (2015), Manajemen Keuangan Perusahaan Teori dan Praktik Edisi 2, Jakarta: Erlangga.

Sugiyono, (2009), Metode Penelitian Bisnis (Pendekatan Kuantitatif, Kualitatif, dan RED). Bandung: Alfabeta

(2015), Metode Penelitian Kuantitatif, Kualitatif, dan RED. Bandung: Alfabeta 
Uzliawati, L., Nofianti, N. dan Ratnasari, D. P., (2016), Struktur Modal, Investment Opportunity Set, Likuiditas dan Nilai Perusahaan. Jurnal Keuangan dan Perbankan, Vol 20 No 2 Mei 2016, page 195-203

Weston, J. F. dan Brigham, E. F., (1999), Dasar-Dasar Manajemen Keuangan Edisi 9 Jilid 1. Jakarta: Erlangga 